\title{
ODNOS RODITELJSKOG PONAŠANJA I OTVORENE I RELACIJSKE AGRESIJE ADOLESCENATA
}

Izvorni znanstveni članak

Primljeno: travanj, 2018.

Prihvaćeno: kolov0z, 2018

UDK 159.922.8:316.642.4-055.52

D0I 10.3935/ljsr.v25i2.231

Marija Šarić

Drnas ${ }^{1}$

orcid.org/0000-0002-9676-7454

Tea Pavin Ivanec ${ }^{2}$

orcid.org/0000-0003-3225-2272

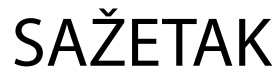

Renata MiljevićRiđički $^{3}$

Cilj ovog istraživanja bio je ispitati može li se otvorena $i$ relacijska agresija mladića i djevojaka predvidjeti na temelju roditeljskog ponašanja njihovih majki i očeva te je li doprinos roditeljskog ponašanja u objašnjavanju agresivnog ponašanja različit ovisno o spolu djeteta $i$ roditelja. $U$ istraživanju je sudjelovalo 605 sudionika (273 djevojke i 332 mladića), učenika trećih razreda srednjih škola. Podaci o otvorenom i relacijski agresivnom ponašanju adolescenata prikupljeni su Upitnikom vršnjačkog konflikta (Marsee i Frick, 2007.), a podaci o percepciji roditeljskog ponašanja prikupljeni su Upitnikom roditeljskog ponašanja (Keresteš i sur., 2012.). Rezultati su pokazali da mladići općenito iskazuju veću razinu otvorene agresije ida očeve percipiraju više podržavajućima, a manje popustljivima u odnosu na djevojke. Kada je riječo otvorenojagresiji mladića, regresijska analiza pokazala je da je njen značajni prediktor veća razina majčine restriktivne kontrole, dok su prediktori otvorene agresije djevojaka veća majčina restriktivna kontrola i popustljivost te slabija očeva roditeljska podrška. Značajnim prediktorima relacijske agresije i mladića i djevojaka pokazali

orcid.org/0000-0002-1217-4687

Sveučilište u Zagrebu

Učiteljski fakultet

Ključne riječi:

otvorena agresija, relacijska agresija, adolescencija, roditeljsko ponašanje.

Dr. sc. Marija Šarić Drnas, psihologinja, e-mail: marija.saric@ufzg.hr

Izv. prof. dr. sc. Tea Pavin Ivanec, psihologinja, e-mail: tea.pavinivanec@ufzg.hr Red. prof. dr. sc. Renata Miljević- Riđički, psihologinja,

e-mail: renata.miljevic@ufzg.hr 
su se i majčina i očeva veća restriktivna kontrola, niža očeva podrška te veća majčina popustljivost. Rezultati istraživanja doprinose razumijevanju složenog odnosa roditeljskog ponašanja i agresivnog ponašanja adolescenata, a mogu biti korisni i različitim stručnjacima koji su uključeni u rad s adolescentima i njihovim roditeljima, te mogu sudjelovati u osmišljavanju i provođenju programa koji bi osvještavali važnost uloge roditeljskog ponašanja i međuovisnost njihovog i djetetovog ponašanja, kako općenito, tako i u kontekstu spolnih razlika.

\section{UVOD}

Brojna istraživanja ukazuju da je roditeljsko ponašanje svakako jedan od značajnijih faktora povezanih s razvojnim ishodima u različitim područjima djetetova razvoja, pa tako i u području socioemocionalnog razvoja, odnosno socijalizaciji djeteta (Maccoby, 2007.). Stoga su roditeljsko ponašanje i stilovi roditeljstva predmet brojnih istraživanja pri čemu je jedan od najčešće spominjanih modela roditeljskih odgojnih stilova u literaturi onaj Diane Baumrind (1967.) koji uključuje autoritativni, autoritarni i popustljivi roditeljski odgojni stil, a koji je ujedno bio i polazišna točka za brojna istraživanja ovog konstrukta. Različiti odgojni stilovi koji zapravo predstavljaju emocionalno ozračje odnosa djeteta i roditelja karakterizirani su i različitim roditeljskim ponašanjima.

Neke od dimenzija koje se susreću u literaturi, a kojima se mogu opisati roditeljska ponašanja, su prihvaćanje/odbijanje, visoka kontrola/nedostatak kontrole, psihološka kontrola/autonomija (Schaefer, 1965., prema Čudina-Obradović i Obradović, 2006.) te roditeljska podrška, bihevioralna kontrola i psihološka kontrola (Barber, Maughan i Olsen, 2005.). Kao što se iz navedenog može uočiti, u literaturi se može naići na različite dimenzije i njihove nazive, no detaljnijim uvidom u njihove opise, u literaturi se također može uočiti i da između pojedinih konstrukata postoje određena sadržajna preklapanja, odnosno da opisuju vrlo slična ponašanja (iscrpan pregled o ovoj temi nude Barber, Maughan i Olsen, 2005.). Kada je riječ o roditeljskim ponašanjima, valja imati na umu da je ono, među ostalim faktorima, određeno i kulturalnim kontekstom, stoga će se u ovom radu roditeljsko ponašanje sagledati iz perspektive globalnih dimenzija koje, na temelju rezultata prikupljenih u hrvatskom kontekstu, predlažu Keresteš i sur. (2012.), a to su roditeljska podrška koja uključuje toplinu u odnosu s djetetom, poticanje djetetove autonomije i induktivnog rezoniranja te znanje o onome što se djetetu u životu događa i kao takva predstavlja širi pojam od roditeljskog prihvaćanja/odbijanja, restriktivna kontrola koja uključuje različite postupke kažnjavanja i intruzivnost te popustljivost kao sklonost roditelja pretjeranom ugađanju djetetovim zahtjevima.

Podaci iz literature upućuju na povezanost roditeljskog ponašanja i različitih mjera prilagodbe djece i mladih poput internaliziranih i eksternaliziranih problema

\section{6 članci}


(Ballash i sur., 2006.; Bean, Barber i Russell Crane, 2006.; Macuka i Smojver-Ažić, 2012.; Klarin i Đerđa, 2014.; Lansford i sur., 2014.) pri čemu se roditeljska toplina konzistentno pokazuje kao zaštitni faktor u psihosocijalnim problemima prilagodbe (Patterson, Cohn i Kao, 1989.; Booth i sur., 1994.; Chen, Rubin i Li, 1997.; Chen, Liu i Li, 2000.; Hoeve i sur., 2009.; Bolkan i sur., 2010.). Mak (1994.) navodi kako percepcija majke kao hladne i visoko kontrolirajuće predstavlja najvažniji prediktor delinkvencije. Za razliku od roditeljske topline, roditeljska kontrola operacionalizira se $u$ dva odvojena konstrukta - bihevioralnu kontrolu i psihološku kontrolu (Grolnick i Pomerantz, 2009.). Bihevioralna kontrola predstavlja roditeljsko ponašanje čiji je cilj regulacija djetetovog ponašanja postavljanjem pravila i granica (Barber i sur., 1994.). Pružajući adolescentu potrebno vodstvo i superviziju, bihevioralna kontrola ima ulogu u pozitivnoj socijalizaciji, tj. regulaciji djetetovog ponašanja prema društvenim normama. Većina istraživanja pokazuje povezanost slabe bihevioralne kontrole i eksternaliziranih problema u ponašanju (Barber i sur., 1994.; Barber, 1996.; Pettit i sur., 2001.; Fletcher, Steinberg i Williams-Wheeler, 2004.; Bean, Barber i Russell Crane., 2006.). Međutim, novija istraživanja ukazuju kako roditeljska popustljivost ne mora nužno biti povezana s nepoželjnim razvojnim ishodima (Bolkan i sur., 2010.), te da za neke adolescente roditeljska popustljivost predstavlja dobar stil roditeljstva (Garcia i Gracia, 2009.). Vjerojatno je da se to događa kad su djeca samoorganizirana i pouzdana, te roditelji koji su topli i osjetljivi za dječje potrebe prihvaćaju da kontrola (više) nije potrebna, a Bolkan i sur. (2010.) navode da ovaj nalaz može biti povezan i s različitim pristupima operacionalizaciji popustljivosti $u$ istraživanjima.

Nadalje, psihološka kontrola predstavlja roditeljska ponašanja kojima se ometa i manipulira djetetovim mislima, osjećajima i privrženosti prema roditeljima, a takva vrsta kontrole nije vođena kontrolom i disciplinom djetetovog ponašanja, već kontrolom djetetovog psihološkog svijeta (Barber i Harmon, 2002.). Karakteristike roditeljske psihološke kontrole impliciraju roditeljski psihološki status u odnosu s djetetom. Prema tome, roditelji ne provode kontrolu zbog discipliniranja djeteta, već zbog zaštite i osiguranja vlastitog položaja u obitelji (Barber i Harmon, 2002.). Psihološka kontrola konzistentno je povezana s negativnim posljedicama za razvoj i prilagodbu djeteta, što se posebno odnosi na internalizirane probleme (Barber i sur., 1994.; Barber, 1996.; Pettit i sur., 2001.; Ballash i sur., 2006.).

U kontekstu istraživanja roditeljskog ponašanja valja napomenuti i da, kada je riječ o doživljaju roditeljskog ponašanja od strane adolescenata, istraživanja spolnih razlika u percepciji dimenzija roditeljskih ponašanja nisu konzistentna (Barber, 1996.; Stattin i Kerr, 2000.; Pettit i sur., 2001.; Rogers, Buchanan i Winchell, 2003.; Soenens i sur., 2008.; Buschgens i sur., 2010.; Wijsbroek i sur., 2011.; Kokkinos, 2014.). Budući da adolescentice općenito pokazuju manje problema u učenju i ponašanju od adolescenata, roditelji mogu vjerovati kako je potrebno vršiti slabiju kontrolu 
nad adolescenticama nego adolescentima (Chen, Liu i Li, 2000.). Na uzorku mlađih adolescenata Macuka, Smojver-Ažić i Burić (2011.) dobile su da dječaci izjavljuju da doživljavaju višu razinu očeve kontrole nego djevojčice, ali i doživljavaju višu razinu odbacivanja i od majke i od oca te manje prihvaćanja od majke. Knezović i Buško (2007.) su na uzorku slične dobi dobile razlike u percepciji majčinog ponašanja u smjeru da djevojčice doživljavaju majke više podržavajućima, a dječaci doživljavaju da ih majke više psihološki kontroliraju. Također, uzimajući u obzir koncept rodnih uloga, gdje se ženama pripisuju ekspresivne, a muškarcima instrumentalne osobine, može se pretpostaviti da će adolescentice percipirati jaču popustljivost majke i oca dok će adolescenti percipirati jaču psihološku kontrolu majke i oca te će se ovim istraživanjem pokušati dobiti uvid i u potencijalne razlike u percepciji roditeljskog ponašanja majki i očeva ovisno o spolu adolescenata.

\section{POVEZANOST RODITELJSKOG PONAŠANJA I AGRESIVNOG PONAŠANJA DJETETA}

Kada je riječ o brojnim istraživanjima o negativnim utjecajima loših roditeljskih postupaka na psihosocijalnu prilagodbu njihove djece, među kojima je i agresivno ponašanje djeteta, valja istaknuti kako se većina istraživanja temelji na podacima ponašanja majki te znatno rjeđe uključuju utjecaj ponašanja očeva (Braza i sur., 2015.). S druge strane, Lamb (2010.) ističe osobine roditelja te kvalitetu veze između roditelja i djeteta kao važnije dimenzije roditeljskog utjecaja od samoga spola roditelja. Drugim riječima, neovisno o spolu roditelja, konzistentno roditeljsko prihvaćanje, toplina i brižnost povezani su sa sigurnom privrženošću djeteta što rezultira pozitivnom prilagodbom. $U$ ovome području predlažu se različita objašnjenja i teorije kao što su teorija socijalnog učenja (Bandura, 1971.) i teorija privrženosti (Bowlby, 1982.). U sklopu teorije socijalnog učenja, agresivno ponašanje može se naučiti opažanjem i oponašanjem agresivnog ponašanja drugih ljudi. U procesu usvajanja ponašanja modela vrlo je bitan proces identifikacije s modelom (Bandura, 1969.) pa se stoga pretpostavlja da će roditeljsko ponašanje imati jači utjecaj u slučaju kada su roditelj i dijete istoga spola nego kada su različitoga spola (npr. Chang i sur., 2003.). Teorija privrženosti tradicionalno se usmjeravala na emocionalnu vezu između novorođenčadi i primarnih skrbnika, odnosno majki (Bowlby, 1982.), no taj se pristup s vremenom mijenja. Suvremena teorija privrženosti primjenjuje razvojnu perspektivu privrženosti te uključuje različita razvojna razdoblja kao i druge modele privrženosti. U novije vrijeme govori se o dvojnoj primarnoj privrženosti - modele primarne privrženosti predstavljaju oba roditelja (Paquette, 2004.; Newland i Coyl, 2010.) te se ističe kako i očevi imaju velik utjecaj, bilo direktan, bilo indirektan, na

\section{8 članci}


prilagodbu svoje djece (Lamb i Lewis, 2004.). Stoga se, prema teoriji privrženosti, ne pretpostavljaju spolne razlike u emocionalnim odgovorima djece na loše roditeljske postupke njihovih majki i očeva (McKee i sur., 2007.).

Kao što je već navedeno, u kontekstu nepovoljnih utjecaja roditeljskog ponašanja na razvojne ishode djece, kao jedan od eksternaliziranih problema često se spominje agresivno ponašanje djece. Agresija se može manifestirati u otvorenom/ fizičkom obliku i relacijskom/socijalnom obliku (Little i sur., 2003.). Otvorena agresija odnosi se na nanošenje štete drugima putem verbalne i fizičke agresije (npr. udaranjem, zastrašivanjem, prijetnjama, vrijeđanjem), a relacijska agresija odnosi se na nanošenje štete drugima putem socijalnih odnosa (npr. ugrožavanjem društvenih veza i osjećaja pripadnosti grupi, ignoriranjem, širenjem glasina, ogovaranjem) (Crick i Grotpeter, 1995.). lako su ova dva oblika agresije uglavnom u umjereno pozitivnoj korelaciji ( $r=0,54$ do 0,76, Crick i Grotpeter, 1995.; Card i sur., 2008.), većina studija navodi da se radi o različitim konstruktima koji su na drugačiji način povezani sa psihosocijalnim problemima prilagodbe (Little i sur., 2003.). Prema metaanalizi Carda i sur. (2008.), otvorena agresija je više povezana s eksternaliziranim problemima, dok je relacijska agresija više povezana s internaliziranim problemima.

Prema teoriji socijalnog učenja, mogu se pretpostaviti različite povezanosti roditeljskih ponašanja i tipova agresije. Drugim riječima, discipliniranje djetetovog ponašanja putem fizičke prisile, iskazivanja moći i zapovijedanja može poslužiti kao model otvoreno agresivnog ponašanja koji dijete može koristiti u odnosima s drugima. Istraživanja konzistentno pokazuju povezanosti između otvorene agresije djeteta i roditeljske kontrole putem fizičke prisile (Nelson i Crick, 2002.). S druge strane, relacijski agresivna djeca mogu imati roditelje koji vrše kontrolu nad njima manipulacijom odnosom roditelj - dijete. U takvom okruženju, djeca mogu naučiti da je manipulacija odnosima i vezama s drugima učinkovit način postizanja cilja. Naime, strategije psihološke kontrole vrlo su slične relacijsko agresivnom ponašanju - npr. uskraćivanje ljubavi, nekonzistentno emocionalno ponašanje i poticanje krivnje. Uskraćivanjem ljubavi djetetu, odnos postaje uvjetovan što roditelj može koristiti u kontroli djeteta, a također i dijete u odnosu s vršnjacima. Takav uvjetovani odnos nadopunjuje se nekonzistentnim emocionalnim ponašanjem pri čemu se osjećaji mijenjaju u skladu s udovoljavanjem zahtjevima (Nelson i Crick, 2002.). Poticanjem krivnje manipulira se impliciranjem kako dijete ili vršnjak neće biti prihvaćeni ukoliko ne promijene svoje ponašanje (Hart i sur., 1998.). Prema tome, pretpostavlja se povezanost između psihološke kontrole roditelja i relacijske agresije djeteta. $\mathrm{Na}$ primjer, djeca čiji roditelji postižu visoke rezultate na psihološkoj kontroli također postižu visoke rezultate na relacijskoj, ali ne i otvorenoj agresiji (Kuppens i sur., 2009.). Međutim, rezultati istraživanja povezanosti između roditeljskog ponašanja i razvoja relacijske agresije nisu konzistentni (Nelson i Crick, 2002.). 
U kontekstu nejednoznačnosti rezultata istraživanja, treba istaknuti i da rezultati istraživanja o povezanosti roditeljskih ponašanja i problema u ponašanju sinova i kćeri nisu konzistentni. Na primjer, nekonzistentna roditeljska kontrola povezana je s problemima u ponašanju sina, ali ne i kćerke (Tung, Li i Lee, 2012.), a očevo hladno i oštro ponašanje više je povezano s agresijom sina nego agresijom kćerke (Chang i sur., 2003.). Nadalje, Rothbaum i Pott (1991.) navode kako je majčino hladno ponašanje više povezano s eksternaliziranim ponašanjem sina nego kćerke, a neki autori navode da je permisivno roditeljstvo povezano s agresijom kćerke, ali ne i sina, dok je zanemarujuće roditeljstvo više povezano s delinkvencijom sina nego kćerke (npr. Sandstrom, 2007;; Hoeve i sur., 2011.; Braza i sur., 2015.). Druga istraživanja ne utvrđuju interakciju između spola djeteta i spola roditelja u povezanosti s eksternaliziranim ponašanjem djeteta (npr. Buehler, Benson i Gerard, 2006.; McKee i sur., 2007.; Browne i sur., 2010.). Nadalje, povezanosti između roditeljskih ponašanja i otvorene i relacijske agresije djece mogu se razlikovati s obzirom na spol roditelja i spol djeteta, a ni u ovom slučaju rezultati istraživanja ne omogućuju jasnije zaključke o odnosu tih varijabli (Hart i sur., 1998.; Nelson i Crick, 2002.; Nelson i sur., 2006., Kuppens i sur., 2009.; Browne i sur., 2010; Braza i sur., 2015.). Nekonzistentnost rezultata navedenih istraživanja ukazuju na važnost dodatnih istraživanja odnosa spola roditelja i spola djeteta u objašnjavanju povezanosti između roditeljskog ponašanja i tipova agresije djeteta, na što je usmjereno i ovo istraživanje.

\section{CILJ, PROBLEMI I HIPOTEZE ISTRAŽIVANJA}

U skladu s prethodno navedenim, cilj ovog istraživanja bio je doprinijeti dosadašnjim spoznajama o međuodnosu agresivnog ponašanja adolescenata i percipiranog roditeljskog ponašanja. Konkretnije, ovim istraživanjem nastojalo se utvrditi postoje li razlike u izraženosti otvorene i relacijske agresije mladića i djevojaka i njihovoj percepciji majčinog i očevog ponašanja, te ispitati doprinos roditeljskog ponašanja u objašnjavanju agresivnog ponašanja adolescenata i adolescentica, odnosno provjeriti mogu li se otvorena i relacijska agresija predvidjeti na temelju roditeljske podrške, restriktivne kontrole te popustljivosti očeva i majki. S obzirom na nalaze dosadašnjih istraživanja, očekuje se da će otvorena agresija biti izraženija među mladićima, dok se u slučaju relacijske agresije takva razlika ne očekuje. Kada je riječ o rodnim razlikama u percepciji dimenzija roditeljskih ponašanja (Bolkan i sur., 2010.), može se pretpostaviti da će i djevojke i mladići percipirati majke više podržavajućima, dok će mladići percipirati veću razinu restriktivne kontrole od strane majki, a djevojke veću razinu popustljivosti od strane očeva. Nadalje, pretpostavka je da će adolescenti koji percipiraju više podržavajućih ponašanja od strane rodi-

\section{0 članci}


telja općenito biti manje skloni iskazivanju agresivnog ponašanja, bilo da se radi o otvorenoj ili relacijskoj agresiji. No, kada je riječ o doprinosu pojedinih dimenzija majčinog i očevog roditeljskog ponašanja otvorenoj i relacijskoj agresiji, pretpostavke nisu specificirane budući da dosadašnja istraživanja u ovom području nisu dala jednoznačne rezultate. Naime, neka istraživanja ukazuju kako se može očekivati da su i majčino i očevo ponašanje prediktori agresivnog ponašanja adolescenata (Nelson i Crick, 2002.; Nelson i sur., 2006.), a neka ukazuju na to da nema efekata majčinih kontrolirajućih i podržavajućih ponašanja na različite eksternalizirane poteškoće adolescenata dok se efekti takvog očevog ponašanja mogu očekivati u slučaju mladića ali ne i djevojaka (Lansford i sur., 2014.) U tom pogledu, ovo istraživanje može predstavljati doprinos razjašnjavanju odnosa roditeljskog ponašanja i agresivnog ponašanja adolescenata.

\section{METODA}

\section{Sudionici i postupak}

U istraživanju je sudjelovalo ukupno 605 učenika trećih razreda osam srednjih škola na području Grada Zagreba od čega 273 djevojke $(45,1 \%)$ i 332 mladića (54,9\%). Budući da je u gimnazijama znatno veći broj djevojaka nego mladića, u uzorak su, osim gimnazija, bile uključene i srednje škole tehničkog usmjerenja (5 gimnazija i 3 škole tehničkog usmjerenja). Inicijalni uzorak bio je veći $(N=656)$, no ovdje su analizirani podaci za one adolescente koji su procijenili roditeljsko ponašanje oba roditelja. S obzirom na dob sudionika, pristanak na istraživanje zatražen je izravno od njih, a roditelji su bili prethodno upoznati s istraživanjem putem pisane obavijesti koju je dobio svaki učenik trećeg razreda. Istraživanje je također prethodno odobreno od strane Etičkog povjerenstva Odsjeka za psihologiju Filozofskog fakulteta u Zagrebu.

Ispitivanje je provedeno grupno uz uputu da je sudjelovanje $u$ istraživanju dobrovoljno te da je ispitivanje anonimno, kao i da će se prikupljeni podaci koristiti u svrhu znanstvenog istraživanja. Podaci su prikupljeni metodom samoiskaza ispunjavanjem upitnika, a vrijeme ispunjavanja upitnika trajalo je otprilike 30 minuta.

\section{Instrumenti}

Podaci o agresivnom ponašanju adolescenata prikupljeni su »Upitnikom vršnjačkog konflikta« (Marsee i Frick, 2007.) koji predstavlja mjeru samoiskaza za adolescente koja uključuje 20 čestica za otvoreni tip agresije (npr. »Započinjem svađu 
kako bih dobio/la ono što želim«) i 20 čestica za relacijski tip agresije (npr. »Kada me netko uzruja, govorim prijateljima da se prestanu družiti s tom osobom «). Sudionici su procjene davali na skali od 0 do 3 , pri čemu 0 znači »u potpunosti netočno«, a 3 znači »u potpunosti točno«. Autori upitnika inicijalno dijele ove dvije kategorije agresije na potkategorije, pa tako navode kako se njime mjere četiri pretpostavljena tipa agresije: proaktivno otvorena agresija, reaktivno otvorena agresija, proaktivno relacijska agresija i reaktivno relacijska agresija. No, faktorskom analizom podataka dobivenih u ovom istraživanju jasno su se izdvojila dva faktora, a to su otvorena i relacijska agresija. Prema tome, u daljnjim analizama rezultat na relacijskoj agresiji izračunat je kao prosjek rezultata sa subskala proaktivno relacijske agresije i reaktivno relacijske agresije, a rezultat na otvorenoj agresiji izračunat je kao prosjek rezultata subskala proaktivno otvorene agresije i reaktivno otvorene agresije. Pouzdanosti obiju skala su zadovoljavajuće pri čemu za skalu otvorene agresije Cronbachov a koeficijent iznosi 0,86 , a za skalu relacijske agresije iznosi 0,84 .

Podaci o roditeljskom ponašanju majki i očeva prikupljeni su »Upitnikom roditeljskog ponašanja« (»URP-29«, Keresteš i sur., 2012.). Upitnik je validiran na hrvatskom uzorku roditelja i djece, što je važno spomenuti budući da je roditeljsko ponašanje povezano, među ostalim, i s kulturalnim kontekstom (Bornstein, 2012.), a sadrži ukupno 29 čestica na kojima su sudionici procjenjivali koliko je određeno ponašanje karakteristično za njihove majke i očeve (dakle, za svakog roditelja zasebno). Procjene su davali na skali od 1 do 4, pri čemu 1 znači »uopće nije točno za nju/ njega«, a 4 znači »u potpunosti je točno za nju/njega«. Upitnik mjeri sedam aspekata roditeljskog ponašanja koji se mogu grupirati u tri globalne dimenzije - roditeljsku podršku (npr. »Pokazuje mi da me voli«), restriktivnu kontrolu (npr. »Viče kad se loše ponašam«) te popustljivost (npr. »Popusti kada se usprotivim njezinom/njegovom zahtjevu«). Ukupni rezultat na svakoj od dimenzija izračunat je kao prosječna vrijednost pripadajućih čestica. Cronbachov a koeficijent za dimenzije upitnika URP-29 kreće se od 0,67 do 0,89.

\section{2 članci}


M. Šarić Drnas, T. Pavin Ivanec, R. Miljević-Riđički: Odnos roditeljskog ponašanja i otvorene i...

\section{REZULTATI}

U prvome dijelu analize izračunati su opći deskriptivni podaci ispitivanih varijabli te su ti podaci prikazani u Tablici 1.

Tablica 1. Deskriptivni podaci ispitivanih varijabli

\begin{tabular}{lcccc}
\hline & M & SD & K-S & a \\
\hline Otvorena agresija & 1,25 & 0,922 & $0,14^{* *}$ & 0,86 \\
Relacijska agresija & 0,78 & 0,704 & $0,15^{* *}$ & 0,84 \\
\hline Majka & & & & \\
Roditeljska podrška & 3,17 & 0,475 & $0,08^{* *}$ & 0,86 \\
Restriktivna kontrola & 2,10 & 0,551 & 0,03 & 0,74 \\
Popustljivost & 2,26 & 0,626 & $0,14^{* *}$ & 0,63 \\
\hline Otac & & & & \\
Roditeljska podrška & 2,92 & 0,596 & $0,06^{* *}$ & 0,90 \\
Restriktivna kontrola & 2,00 & 0,572 & $0,06^{* *}$ & 0,76 \\
Popustljivost & 2,04 & 0,723 & $0,10^{* *}$ & 0,76 \\
\hline
\end{tabular}

${ }^{* *} \mathrm{p}<0,01$

Normalnost distribucija ispitivanih varijabli testirana je Kolmogorov-Smirnovljevim testom, a iz Tablice 1. vidljivo je kako distribucije svih ispitivanih varijabli osim majčine restriktivne kontrole odstupaju od normalne što kod većih uzoraka, s obzirom na osjetljivost ovog testa, nije neočekivano (Tabachnick i Fidell, 2001.). Uvidom u distribucije varijabli, utvrdilo se kako većina distribucija pokazuje pozitivnu asimetriju, dok je negativna asimetrija uočena za varijablu roditeljske podrške i u slučaju majki i u slučaju očeva. Daljnjim uvidom u zakrivljenosti i asimetričnosti distribucija rezultata utvrđeno je kako nema trenda ekstremnih odstupanja navedenih parametara te su u obradi rezultata korišteni parametrijski statistički postupci (Kline, 2005.).

Prije odgovora na probleme istraživanja, preliminarno su analizirane korelacije ispitivanih varijabli koje su, zasebno za mladiće, a zasebno za djevojke, prikazane u Tablici 2. 
Tablica 2. Korelacije među ispitivanim varijablama na uzorku adolescenata $(\mathrm{N}=$ 332) i adolescentica $(\mathrm{N}=273)$

\begin{tabular}{|c|c|c|c|c|c|c|c|c|}
\hline & 1. & 2. & 3. & 4. & 5. & 6. & 7. & 8. \\
\hline $\begin{array}{l}\text { 1. Otvorena } \\
\text { agresija }\end{array}$ & - & $0,57^{* *}$ & $-0,11$ & $0,26^{* *}$ & $0,27^{* *}$ & $-0,21^{* *}$ & $0,24^{* *}$ & 0,09 \\
\hline $\begin{array}{l}\text { 2. Relacijska } \\
\text { agresija }\end{array}$ & $0,62^{* *}$ & - & $-0,08$ & $0,24^{* *}$ & $0,19^{* *}$ & $-0,20^{* *}$ & $0,24^{* *}$ & 0,07 \\
\hline $\begin{array}{l}\text { 3. Majka - } \\
\text { roditeljska } \\
\text { podrška }\end{array}$ & $-0,12^{*}$ & $-0,16^{* *}$ & - & $-0,33^{* *}$ & 0,03 & $0,51^{* *}$ & $-0,09$ & $-0,04$ \\
\hline $\begin{array}{l}\text { 4. Majka - } \\
\text { restriktivna } \\
\text { kontrola }\end{array}$ & $0,31^{* *}$ & $0,34^{* *}$ & $-0,08$ & - & $-0,01$ & $-0,12^{*}$ & $0,50^{* *}$ & 0,12 \\
\hline $\begin{array}{l}\text { 5. Majka - } \\
\text { popustljivost }\end{array}$ & 0,09 & $0,23^{* *}$ & $-0,09$ & 0,02 & - & $-0,13^{*}$ & 0,10 & $0,29 * *$ \\
\hline $\begin{array}{l}\text { 6. Otac - } \\
\text { roditeljska } \\
\text { podrška }\end{array}$ & $-0,01$ & $-0,19 * *$ & $0,52^{* *}$ & 0,01 & $-0,13^{*}$ & - & $-0,07$ & 0,03 \\
\hline $\begin{array}{l}\text { 7. Otac - } \\
\text { restriktivna } \\
\text { kontrola }\end{array}$ & $0,22^{* *}$ & $0,32^{* *}$ & 0,07 & $0,53^{* *}$ & $0,11^{*}$ & 0,03 & - & $-0,19^{* *}$ \\
\hline $\begin{array}{l}\text { 8. Otac - } \\
\text { popustljivost }\end{array}$ & $0,15^{* *}$ & $0,17^{* *}$ & $-0,08$ & $0,20^{* *}$ & $0,28^{* *}$ & 0,07 & 0,01 & - \\
\hline
\end{tabular}

${ }^{*} p<0,05 ;{ }^{* *} p<0,01$

Napomena: korelacije ispod dijagonale odnose se na mladiće, a iznad dijagonale na djevojke

Iz Tablice 2. vidljivo je kako postoji značajna pozitivna povezanost između otvorene i relacijske agresije, dakle oni adolescenti koji pokazuju više otvoreno agresivnih ponašanja ujedno su skloniji i relacijsko agresivnim ponašanjima. Nadalje, postoji značajna pozitivna povezanost između procjena globalnih dimenzija majčine i očeve roditeljske podrške, dakle adolescenti koji percipiraju majke više podržavajućima takvima percipiraju i očeve, a isti trend može se uočiti i u slučaju dimenzija restriktivne kontrole i popustljivosti.

\section{4 članci}




\section{OTVORENA I RELACIJSKA AGRESIJE MLADIĆA I DJEVOJAKA I NJIHOVA PERCEPCIJA RODITELJSKOG PONAŠANJA}

Daljnjom analizom podataka provjereno je razlikuje li se razina pojedine vrste agresivnog ponašanja te percepcija roditeljskog ponašanja majki i očeva s obzirom na spol adolescenata, a dobiveni rezultati prikazani su u Tablici 3.

Tablica 3. Razlike u prosječnim rezultatima na ispitivanim varijablama s obzirom na spol adolescenata

\begin{tabular}{lccccc}
\hline & \multicolumn{2}{c}{ Mladići (N = 332) } & \multicolumn{2}{c}{ Djevojke (N= 273) } & \multirow{2}{*}{ t } \\
\cline { 2 - 5 } & $\mathbf{M}$ & $\mathbf{S D}$ & $\mathbf{M}$ & $\mathbf{S D}$ & \\
\hline Otvorena agresija & 1,25 & 0,922 & 0,97 & 0,658 & $4,18^{* *}$ \\
Relacijska agresija & 0,78 & 0,704 & 0,87 & 0,641 & $-1,69$ \\
\hline Majka & & & & & \\
Roditeljska podrška & 3,17 & 0,475 & 3,25 & 0,510 & $-1,91$ \\
Restriktivna kontrola & 2,10 & 0,551 & 2,12 & 0,591 & $-0,43$ \\
Popustljivost & 2,26 & 0,626 & 2,32 & 0,624 & 1,58 \\
\hline Otac & & & & & \\
Roditeljska podrška & 2,92 & 0,596 & 2,84 & 0,692 & $2,32^{*}$ \\
Restriktivna kontrola & 2,00 & 0,572 & 1,89 & 0,604 & $-1,19$ \\
Popustljivost & 2,04 & 0,723 & 2,49 & 0,783 & $-7,37^{* *}$ \\
\hline
\end{tabular}

${ }^{*} p<0,05 ; * * p<0,01$

Testiranje razlika između prosječnih rezultata mladića i djevojaka na otvorenoj i relacijskoj agresiji pokazalo je kako su samoprocjene mladića na skali otvorene agresije statistički značajno više nego samoprocjene djevojaka. S druge strane, kada je riječ o relacijskoj agresiji, nema značajne razlike između samoprocjena mladića i djevojaka.

Kada je riječ o razlikama između mladića i djevojaka u procjeni roditeljskog ponašanja, iz podataka prikazanih u Tablici 3. može se uočiti kako su majke i očevi na većini dimenzija procijenjeni podjednako, dok su razlike s obzirom na spol adolescenata dobivene u slučaju percipirane očeve podrške i popustljivosti. Pri tome mladići procjenjuju da dobivaju više podrške od očeva, dok djevojke procjenjuju očeve popustljivijima. Razlike u procjeni roditeljske restriktivne kontrole nisu utvrđene. 


\section{POVEZANOST RODITELJSKIH PONAŠANJA MAJKE I OCA S OTVORENOM AGRESIJOM ADOLESCENATA I ADOLESCENTICA}

Kako bi se provjerilo doprinose li iste dimenzije majčinog i očevog roditeljskog ponašanja otvorenoj i relacijskoj agresiji mladića i djevojaka, provedene su četiri regresijske analize u kojima su prediktorske varijable dimenzije majčinog $i$ očevog roditeljskog ponašanja, a kriterijske varijable otvoreno i relacijsko agresivno ponašanje mladića i djevojaka (Tablica 4. i Tablica 5.). U regresijske analize sve su dimenzije majčinog i očevog roditeljskog ponašanja uvrštene $u$ istom bloku budući da, s obzirom na nejednoznačne rezultate dosadašnjih istraživanja, zapravo nema jasnog uporišta prema kojem bi se u zasebnim koracima (hijerarhijski) određenim redoslijedom uvrstilo prvo ponašanje jednog, a zatim drugog roditelja, posebno ako se uzme u obzir i perspektiva dvojne primarne privrženosti.

Tablica 4. Rezultati regresijskih analiza za kriterijsku varijablu otvorene agresije

\begin{tabular}{lcccc}
\hline \multirow{2}{*}{ Prediktori } & \multicolumn{2}{c}{ Mladići } & \multicolumn{2}{c}{ Djevojke } \\
\cline { 2 - 5 } Majka & $\boldsymbol{\beta}$ & $\mathbf{t}$ & $\boldsymbol{\beta}$ & $\mathbf{t}$ \\
Roditeljska podrška & $-0,05$ & $-0,87$ & 0,05 & 0,75 \\
Restriktivna kontrola & 0,24 & $3,74^{* *}$ & 0,19 & $2,68^{* *}$ \\
Popustljivost & 0,04 & 0,63 & 0,22 & $3,62^{* *}$ \\
Otac & & & & \\
Roditeljska podrška & $-0,08$ & $-1,23$ & $-0,18$ & $-2,65^{* *}$ \\
Restriktivna kontrola & 0,09 & 1,45 & 0,12 & 1,70 \\
Popustljivost & 0,10 & 1,68 & 0,04 & 0,60 \\
\hline & $\mathrm{R}=0,35 ; R^{2}=0,13$ & \multicolumn{2}{c}{$\mathrm{R}=0,41 ; \mathrm{R}^{2}=0,15$} \\
& $\mathrm{~F}(6 / 325)=7,76^{* *}$ & $\mathrm{~F}(6 / 266)=9,11^{* *}$ \\
\hline
\end{tabular}

${ }^{* *} \mathrm{p}<0,01$ 
M. Šarić Drnas, T. Pavin Ivanec, R. Miljević-Riđički: Odnos roditeljskog ponašanja i otvorene i...

Tablica 5. Rezultati regresijskih analiza za kriterijsku varijablu relacijske agresije

\begin{tabular}{lcccc}
\hline \multirow{2}{*}{ Prediktori } & \multicolumn{2}{c}{ Mladići } & \multicolumn{2}{c}{ Djevojke } \\
\cline { 2 - 5 } Majka & $\boldsymbol{\beta}$ & $\mathbf{t}$ & $\boldsymbol{B}$ & $\mathbf{t}$ \\
Roditeljska podrška & $-0,06$ & $-1,06$ & 0,09 & 1,26 \\
Restriktivna kontrola & 0,21 & $3,53^{* *}$ & 0,16 & $2,25^{*}$ \\
Popustljivost & 0,15 & $2,81^{* *}$ & 0,13 & $2,12^{*}$ \\
Otac & & & & \\
Roditeljska podrška & $-0,15$ & $-2,50^{*}$ & $-0,20$ & $-2,91^{* *}$ \\
Restriktivna kontrola & 0,20 & $3,36^{* *}$ & 0,15 & $2,06^{*}$ \\
Popustljivost & 0,09 & 1,74 & 0,05 & 0,81 \\
\hline & $\mathrm{R}=0,47 ; R^{2}=0,22$ & $\mathrm{R}=0,37 ; \mathrm{R}^{2}=0,13$ \\
& $\mathrm{~F}(6 / 325)=15,57^{* *}$ & $\mathrm{~F}(6 / 266)=6,88^{* *}$ \\
\hline
\end{tabular}

${ }^{*} p<0,05 ; * * p<0,01$

Kada je riječ o otvorenoj agresiji, već prethodno navedeni podaci o korelacijama (Tablica 2.) pokazali su da su i majčina i očeva restriktivna kontrola značajno pozitivno povezane s otvorenom agresijom i adolescenata i adolescentica, međutim, rezultati regresijske analize ukazuju da se značajnim prediktorom otvorene agresije kako mladića, tako i djevojaka pokazala samo majčina restriktivna kontrola. Očeva restriktivna kontrola se, s druge strane, nije pokazala značajnim prediktorom otvorene agresije niti mladića niti djevojaka. Nadalje, roditeljska podrška dijelom se pokazala značajnim prediktorom agresivnog ponašanja adolescenata. Naime, rezultati ukazuju da su djevojke koje očeve percipiraju manje podržavajućima sklonije i otvorenoj i relacijskoj agresiji, a da su mladići koji očeve percipiraju na takav način skloniji relacijskoj agresiji. Efekt očeve podrške nije se pokazao značajnim u slučaju otvorene agresije mladića, a značajnim se nije pokazao niti efekt majčine podrške, ni u slučaju agresivnog ponašanja mladića niti u slučaju djevojaka. Kada je riječ o roditeljskoj popustljivosti, rezultati pokazuju da očeva popustljivost nije povezana s agresivnim ponašanjem adolescenata. $S$ druge strane, majčina popustljivost pokazala se značajnim pozitivnim prediktorom otvorene i relacijske agresije djevojaka te relacijske agresije mladića. 


\section{RASPRAVA}

Rezultati koji govore o značajnoj pozitivnoj povezanosti između otvorene i relacijske agresije u skladu su s rezultatima dosadašnjih istraživanja (Smith, Rose i Schwartz-Mette, 2010.). Nadalje, i rezultati koji ukazuju na to da se majčino i očevo ponašanje u određenoj mjeri percipira sličnim u skladu su s nalazima iz literature koji također navode sličnost u percepciji roditeljskog ponašanja očeva i majki, kako mlađe djece tako i adolescenata (Winsler, Madigan i Aquilino, 2005.; McDermott i sur., 2014.; Tavassolie i sur., 2016.).

Usporedba prosječnih rezultata mladića i djevojaka na skalama otvorene i relacijske agresije pokazala je da su samoprocjene mladića u slučaju otvorene agresije značajno više, dok u slučaju relacijske agresije razlike nema. Ovi podaci vezani uz otvorenu agresiju u skladu su s prethodnim istraživanjima koja konzistentno ukazuju kako je otvorena agresija izraženija među mladićima (Nichols i sur., 2006.; Šarić, 2017.). No, kada je riječ o indirektnoj ili relacijskoj agresiji, nalazi iz literature nisu tako konzistentni (Björqvist, Lagerspetz i Kaukiainen, 1992.; Crick i Grotpeter, 1995.; Archer, 2004.; Salmivalli i Kaukiainen, 2004.; Smith, Rose i Schwartz-Mette, 2010.; Šarić, 2017.). U nekima od navedenih istraživanja ova je razlika utvrđena u smjeru da je relacijski oblik agresije izraženiji među djevojkama, pa se čak nekad naziva i »ženskom agresijom« (Nichols i sur., 2006.). S druge strane, neka istraživanja navode kako je ovaj oblik izraženiji među mladićima (David i Kistner, 2000.; Salmivalli i Kaukiainen, 2004.) povezujući to s općenito višom razinom agresivnog ponašanja među mladićima, dok neka istraživanja ovu razliku nisu potvrdila (Björqvist, Lagerspetz i Kaukiainen, 1992.; Zimmer-Gembeck, Geiger i Crick, 2005.) što je rezultat koji je dobiven i u ovom istraživanju. Moguće je da se u podlozi ovih rezultata, odnosno nepostojanju razlike u relacijskoj agresiji, nalazi korištena metoda procjene agresivnog ponašanja, a to je metoda samoprocjene. Naime, neki nalazi iz literature ukazuju da se, kad je o relacijskoj agresiji riječ, razlike »u korist djevojaka« dobivaju kad se kao mjera agresivnog ponašanja koriste vršnjačke procjene (Archer, 2004.) što nije bio slučaj u ovom istraživanju. Nadalje, Smith, Rose i Schwartz-Mette (2009.) navode da izostanak ove razlike može biti povezan i s time što su otvorena i relacijska agresija u pozitivnoj korelaciji, a kako je otvoreno agresivno ponašanje sustavno prisutnije među mladićima, moguće je da je to u podlozi izostanka razlika u relacijskoj agresiji te bi se istraživanja trebala više usmjeriti na kontroliranje spomenutih efekata preklapanja različitih oblika agresivnog ponašanja.

Kada je riječ o percepciji roditeljskog ponašanja, razlike s obzirom na spol adolescenata dobivene su u slučaju percepcije očeve podrške i popustljivosti, pri čemu mladići procjenjuju da im očevi pružaju više podrške, a djevojke percipiraju očeve popustljivijima. $U$ procjeni ostalih aspekata roditeljskog ponašanja značajne

\section{8 članci}


razlike nisu utvrđene. Keresteš (2002.) navodi kako majke i očevi više kontroliraju sinove nego kćeri, a Olivari i sur. (2015.) navode kako su upravo majke te koje su češće percipirane više kontrolirajućima, no adolescenti iz ovog uzorka procjenjuju da se njihovi očevi i majke podjednako ponašaju kad je riječ o dimenziji kontrole. Kada je riječ o razlici u percipiranoj roditeljskoj podršci očeva, Bolkan i sur. (2010.) navode da je moguće da mladići očeve percipiraju kao nekoga koga češće pitaju za savjet i s kime češće provode slobodno vrijeme. Kako su ta ponašanja karakteristična upravo za konstrukt roditeljske podrške, navedene pretpostavke iz literature mogle bi se povezati i s rezultatima dobivenima u ovom istraživanju. Nadalje, dobivena razlika u percepciji očeve podrške može se sagledati i u kontekstu teorije socijalnog učenja, gdje otac predstavljajući sinu model ponašanja, aktivno pruža podršku u oblikovanju željenog ponašanja, a dobivena razlika u percepciji očeve popustljivosti može se povezati s nalazima Bronte-Tinkewe, Mooree i Carranoe (2006.) koji pokazuju da očevi više kontroliraju ponašanje sinova nego kćeri. Starrels (1994.) navodi da su očevi više uključeni u odgoj sina pri čemu se koncentriraju na instrumentalne oblike potpore i discipline. Također, još su Rothbart i Maccoby (1966.) pokazali da očevi iskazuju veću popustljivost prema djevojkama nego prema mladićima. Među objašnjenjima navode da roditelji ne dopuštaju djetetu istoga spola ona ponašanja koja ne dopuštaju ni sebi, pri čemu su popustljiviji prema djetetu suprotnoga spola. Bolkan i sur. (2010.) navode da razlike u ponašanju očeva i majki mogu proizlaziti i iz njihovih različitih uloga u kućanstvu. Prema tome, dobivena razlika u očevoj popustljivosti također se može objasniti teorijom socijalnog učenja gdje je otac više uključen u modeliranje ponašanja sina nego kćerke. S druge strane, Olivari i sur. (2015.) nisu dobili razliku u percepciji očeve popustljivosti s obzirom na spol adolescenata, dok su dobili da mladići procjenjuju majke popustljivijima, što bi se također moglo povezati s već navedenim češćim roditeljskim modeliranjem ponašanja djetetu istog spola. Dodatna analiza usporedbe procjena majki i očeva na cijelome uzorku pokazala je kako adolescenti koji su sudjelovali u ovom istraživanju, bez obzira na spol, općenito daju više procjene majkama kada je riječ o globalnim dimenzijama roditeljske podrške, ali i kontrole, što je u skladu s rezultatima prethodnih istraživanja (npr. Lansford i sur., 2014.; Olivari i sur., 2015.), dok razlike na dimenziji popustljivosti nema. $U$ podlozi ovih rezultata može biti to što su majke te koje općenito više vremena provode u aktivnostima vezanim uz odgoj djece i brigu o djeci (Craig, 2006.; McMunn i sur., 2017.). Ukoliko je majka češće u interakciji s djetetom, povećava se i vjerojatnost da dijete više razgovara s njom te da je s njom bliskije, odnosno intimnije (Kosterman i sur., 2004.), što može rezultirati i većim brojem elemenata, odnosno situacija koje su osnova za procjenu roditelja kada je riječ o različitim aspektima podrške (npr. poticanje induktivnog rezoniranja kroz češće razgovore, roditeljsko znanje kroz razgovor o djetetovim aktivnostima, 
prijateljima i sl.). Također se, s obzirom da je emocionalna toplina jedan od aspekata roditeljske podrške, čini opravdanim pretpostaviti kako dio razlika u percepciji majčine i očeve roditeljske podrške može u podlozi imati i potencijalne razlike u izražavanju emocija između muškaraca i žena. Naime, istraživanja sugeriraju različitu ulogu očeva i majki u odgoju djece pri čemu se očevima više pripisuje instrumentalna uloga dok se majkama više pripisuje ekspresivna uloga (Collins i Russell, 1991.; Craig, 2006.). Tako je Macuka (2010.) u svom istraživanju dobila kako majke sebe procjenjuju višima na dimenziji emocionalnosti, odnosno prihvaćanja djeteta, dok razlike u kontroli (psihološkoj i bihevioralnoj) u procjenama majki i očeva nije bilo.

U kontekstu odnosa roditeljskog ponašanja i agresivnog ponašanja adolescenata, rezultati pokazuju da su majčina i očeva restriktivna kontrola značajno pozitivno povezane s otvorenom agresijom i adolescenata i adolescentica, što je $u$ skladu s nalazima prethodnih istraživanja (npr. Nelson i Crick, 2002.; Lansford i sur., 2014.) i ukazuje na povezanost između otvorene agresije i roditeljske kontrole putem fizičke prisile. Kao što je već spomenuto, dobiveni rezultat može se sagledati iz perspektive teorije socijalnog učenja prema kojoj discipliniranje djetetovog ponašanja putem fizičke prisile može poslužiti kao model ponašanja koji dijete može koristiti u odnosima s drugima. No, kada je riječ o restriktivnoj kontroli, rezultati regresijske analize ukazuju da je značajan prediktor otvorene agresije i mladića i djevojaka samo majčina restriktivna kontrola, ali ne i očeva. Dobiveni rezultat u skladu je s nalazima Harta i sur. (1998.) prema kojima su majčina, ali ne i očeva kontrolirajuća ponašanja povezana s otvorenom agresijom mladića i djevojaka. Naime, djeca mogu reagirati emocionalno negativnije na kritiziranje i kažnjavanje od roditelja od kojega se takvo ponašanje manje očekuje, tj. od majki kojima se tradicionalno pripisuje ekspresivna uloga (Chang i sur., 2003.), a pritom je i majka često skrbnik s kojim su adolescenti najviše u interakciji (Rogers, Bouchanan i Winchell, 2003.; Bolkan i sur., 2010.). Važnost samo majčine restriktivne kontrole može se povezati i s rezultatima istraživanja koje su na uzorku japanskih adolescenata dobili Kawabata i Crick (2016.). Oni su, naime, dobili da je majčina relacijska agresija povezana s više otvorene agresije prema vršnjacima i kod mladića i kod djevojaka.

Kada je riječ o roditeljskoj podršci, dobiveni rezultati pokazuju da su i otvorenoj i relacijskoj agresiji sklonije one djevojke koje očeve percipiraju manje podržavajućima, a mladići koji očeve vide takvima su skloniji relacijskoj agresiji. S druge strane, majčina podrška nije se pokazala značajnim prediktorom agresivnog ponašanja niti djevojaka niti mladića. Dobiveni rezultat dijelom je u skladu s metaanalizom Rothbauma i Pott (1991.) koji zaključuju da slabo roditeljsko prihvaćanje može rezultirati eksternaliziranim ponašanjem djeteta suprotnoga spola, a Lansford i sur. (2014.) dobili su kako je to slučaj kad je riječ o ponašanju mladića. Kada je riječ o odnosu roditeljskog prihvaćanja i relacijske agresije, rezultati dobiveni u ovom istraživanju

\section{0 članci}


također su dijelom u skladu s onime što su dobile Knezović i Buško (2007.) na uzorku starijih osnovnoškolaca, a to je da je dimenzija očevog prihvaćanja djeteta negativan prediktor djetetove indirektne agresije.

U slučaju roditeljske popustljivosti, rezultati su pokazali da je percepcija majke kao popustljive značajan pozitivan prediktor otvorene i relacijske agresije djevojaka te relacijske agresije mladića, dok se percepcija očeve popustljivosti nije pokazala značajnim prediktorom agresivnog ponašanja adolescenata. Dakle, i u ovom slučaju možemo zaključiti kako su dobiveni rezultati u skladu s teorijom socijalnog učenja prema kojoj se pretpostavlja da se može očekivati nešto jači utjecaj roditeljskog ponašanja kada su roditelj i dijete istoga spola nego kada su različitoga spola (Chang i sur., 2003.).

Uočava se da otvorenu agresiju mladića značajno predviđa jedino restriktivna kontrola majke, dok otvorenu agresiju djevojaka značajno predviđaju majčina restriktivna kontrola i popustljivost te slaba očeva podrška. Dobiveni rezultat može se pripisati spolnoj razlici u otvorenoj agresiji gdje mladići postižu značajno više rezultate od djevojaka (Šarić, 2017.), a što je dobiveno i u ovom istraživanju. Prema tome, budući da je otvorena agresija kod mladića društveno prihvatljivija nego kod djevojaka (Nichols i sur., 2006.), moguće je da su za njezinu manifestaciju kod djevojaka potrebni dodatni utjecaji nepoželjnog roditeljskog ponašanja kao što su slaba roditeljska podrška i popustljivost, odnosno određena kombinacija majčinog i očevog ponašanja. U slučaju relacijske agresije, i majčina i očeva restriktivna kontrola pokazale su se njezinim značajnim pozitivnim prediktorima. Naime, i mladići i djevojke koji roditelje percipiraju više kontrolirajućima skloniji su relacijsko-agresivnim ponašanjima. Ovi rezultati mogu se povezati s nalazima nekih istraživanja koja ukazuju da je veća vjerojatnost da će se relacijska agresija javiti ako i sami roditelji koriste neki oblik kontrole koji uključuje takva ponašanja (Barber i sur., 1994.; Barber, 1996.; Pettit i sur., 2001.; Ballash i sur., 2006.; Albrecht, Galambos i Jansson, 2007.). Nadalje, rezultati ukazuju kako se majčina podrška nije pokazala značajnim prediktorom relacijske agresije adolescenata, no očeva podrška jest i to u smjeru da je nedostatak očeve podrške značajno povezan s višom razinom relacijske agresije i mladića i djevojaka. Majčina popustljivost nije se pokazala značajnim prediktorom relacijske agresije niti mladića niti djevojaka.

Prije samog zaključka valja se osvrnuti i na neke nedostatke ovog istraživanja koji bi se trebali uzeti u obzir pri interpretaciji dobivenih rezultata. Riječ je o korelacijskom istraživanju koje ne omogućava zaključivanje o uzročno-posljedičnim vezama. Također, podaci o agresivnom ponašanju adolescenata prikupljeni su metodom samoprocjene, što može predstavljati poteškoću (iz perspektive socijalno poželjnih odgovora) te bi bilo korisno uključiti i mjere procjene od strane drugih osoba (npr. vršnjaka, roditelja ili nastavnika). Naime, moguće je da bi korištenje drugačijih 
metoda procjene rezultiralo i drugačijim nalazima, kao što neki nalazi iz literature impliciraju (Smith, Rose i Schwartz-Mette, 2010.) te o tome treba voditi računa u kontekstu dometa zaključivanja na temelju dobivenih rezultata. Također, treba imati u vidu i relativno nisku pouzdanost subskale popustljivosti majke u odnosu na ostale subskale (moguće je da je u podlozi toga činjenica da je riječ o vrlo kratkoj skali, u odnosu na subskale koje ispituju ostale globalne dimenzije roditeljskog ponašanja, no s obzirom da ista subskala u slučaju procjene ponašanja očeva ima višu pouzdanost, ovime bi možda trebalo pristupiti kao zasebnom psihometrijskom problemu). U budućim istraživanjima također bi trebalo uključiti i roditeljske samoprocjene vlastitog ponašanja kako bi se provjerilo potvrđuju li se rezultati dobiveni na temelju djetetovih procjena. Nadalje, svakako je važno istaknuti da ovo istraživanje ne uključuje razne druge čimbenike koji mogu imati značajnu ulogu u razini otvorene i relacijske agresije poput mogućih poteškoća povezanih s prilagodbom u razdoblju adolescencije općenito, ali nekih karakteristika temperamenta i osobina ličnosti povezanih sa samokontrolom koja može imati važnu ulogu u objašnjavanju agresivnog ponašanja (Smits, de Boeck i Vansteelandt, 2004.; Nichols i sur., 2006.). Naime, neka istraživanja ukazuju na to da je razina roditeljske podrške pozitivno povezana s djetetovim lakšim temperamentom dok su roditeljsko odbijanje i razina kontrole pozitivno povezani s težim temperamentom djeteta (npr. Putnam, Sanson i Rothbart, 2002.; Laukkanen i sur., 2014.). Nadalje, roditeljska podrška, odnosno dimenzija topline/prihvaćanja povezana je i s privrženošću, a djeca koja nisu razvila sigurnu privrženost iskazuju višu razinu agresivnosti u odnosu na sigurno privrženu djecu (Eliot i Cornell, 2009.) te su sklonija i biti počinitelji vršnjačkog zlostavljanja (Kõiv, 2012.). Također, nije uzeto u razmatranje stanje u domu, u smislu obiteljskih promjena, rastavljenih roditelja, očuha/pomajki i sl. Neka istraživanja ukazuju da su nepovoljne obiteljske okolnosti jači rizični faktor za dječake nego za djevojčice, ali i da su česte nepovoljne promjene važniji prediktor za agresivno ponašanje kod djevojčica (Nichols i sur.,2006.). U svakom slučaju, obiteljsko okruženje moglo bi biti jaki medijator ili moderator agresivnog ponašanja adolescenata (ali i roditeljskog ponašanja), te bi ga valjalo uzeti u obzir u budućim istraživanjima.

\section{ZAKLJUČAK}

Zaključno, može se reći kako rezultati provedenog istraživanja sugeriraju da bi se prilikom ispitivanja povezanosti između roditeljskog ponašanja i djetetovog agresivnog ponašanja u obzir trebali uzeti i spol roditelja i spol djeteta, odnosno njihova moguća interakcija, ali i potencijalne razlike u percepciji roditeljskog ponašanja ovisno o spolu djeteta. Ovo istraživanje podupire dosadašnje nalaze koji ukazuju na to da je među mladićima općenito izraženija otvorena agresija nego

\section{2 članci}


među djevojkama te da postoje neke razlike u percepciji roditeljskog ponašanja majki i očeva ovisno o spolu djeteta, prvenstveno vezane uz ponašanje očeva koje mladići doživljavaju više podržavajućima, a djevojke popustljivijima. Kada je riječ o predviđanju agresivnog ponašanja adolescenata, dobiveni rezultati ukazuju kako izraženiju otvorenu agresiju općenito možemo očekivati među mladićima i djevojkama čije su majke sklonije kontrolirajućim ponašanjima. Također, otvorena agresija djevojaka izraženija je ako majku percipiraju popustljivijom, te ako doživljavaju slabiju roditeljsku podršku od oca. U slučaju relacijske agresije, rezultati su pokazali da će se takav oblik agresije vjerojatnije javiti među mladićima i djevojkama koji doživljavaju više kontrole od majki i očeva, a k tome i očeve percipiraju manje podržavajućima, a majke popustljivijima. U usporedbi s otvorenom agresijom, relacijska agresija može se bolje predvidjeti na temelju različitih majčinih i očevih ponašanja.

Rezultati ovog istraživanja mogu doprinijeti boljem razumijevanju korelata agresivnog ponašanja adolescenata, odnosno može se reći kako je doprinos ovog istraživanja u dodatnom uvidu u složenu interakciju ponašanja djece i roditelja, a dobiveni rezultati mogu biti poticaj za daljnja istraživanja. Također, dobiveni rezultati mogu biti korisni i različitim stručnjacima koji su na različite načine uključeni u rad s adolescentima i/ili njihovim roditeljima. Naime, za prevenciju agresivnog ponašanja djece svakako je važno obratiti pažnju i na roditeljska ponašanja, odnosno važan je praktičan rad s roditeljima te se u sklopu različitih edukacija i intervencijskih programa osmišljenih za roditelje u njih može razvijati svijest o međuodnosu roditeljskog i djetetovog ponašanja te mogućnosti izbjegavanja (ili smanjivanja vjerojatnosti) pojave nepoželjnih ponašanja. Konkretnije, roditeljima se može ukazati na to kako neka njihova specifična ponašanja mogu biti povezana s nekim specifičnim ponašanjima njihovog djeteta; u ovom kontekstu s različitim oblicima agresivnog ponašanja, ali i kako su ona povezana s razvojem rodnih uloga. Pri tom bi svakako bilo poželjno da roditelji imaju prilike čuti o tome dok su njihova djeca u mlađoj dobi (a ne tek u adolescenciji), no u nekoj prilagođenoj varijanti mogu biti korisni i za roditelje adolescenata. $U$ tom pogledu, valja istaknuti važnost uloge svih stručnjaka koji na različite načine sudjeluju u brizi o dobrobiti djece i mogu doprinijeti poboljšanju kvalitete djetetova razvoja, poput djelatnika u sustavu odgoja i obrazovanja, socijalne skrbi i zdravstva koji mogu prepoznati i ukazati na potrebu za ovakvim programima, ali i sudjelovati u njihovom osmišljavanju i provođenju. 


\section{LITERATURA}

1. Albrecht, A. K., Galambos, N. L. \& Jansson, S. M. (2007). Adolescents' internalizing and aggressive behaviors and perceptions of parents' psychological control: $\mathrm{A}$ panel study examining direction of effects. Journal of Youth and Adolescence, $36(5), 673-684$.

2. Archer, J. (2004). Sex differences in aggression in real-world settings: A meta-analytic review. Review of General Psychology, 8 (4), 291-322.

3. Ballash, N., Leyfer, O., Buckley, A. F. \& Woodruff-Borden, J. (2006). Parental control in the etiology of anxiety. Clinical Child and Family Psychology Review, 9 (2), 113-133.

4. Bandura, A. (1969). Social-learning theory of identificatory processes: Handbook of socialization theory and research. Chicago: Rand McNally.

5. Bandura, A. (1971). Social Learning Theory. New York City: General Learning Press.

6. Barber, B. K. (1996). Parental psychological control: Revisiting a neglected construct. Child Development, 67 (6), 3296-3319. https://doi.org/10.1111/j.1467-8624.1996. tb01915.x

7. Barber, B. K., Olsen, J. E. \& Shagle, S. C. (1994). Associations between parental psychological and behavioral control and youth internalized and externalized behaviors. Child Development, 65, 1120-1136. https://doi.org/10.1111/j.1467-8624.1994. tb00807.x

8. Barber, B. K. \& Harmon, E. L. (2002). Violating the self: Parental psychological control of children and adolescents. In: Barber, B. K. (ed.), Intrusive parenting: How psychologicalcontrol affects children and adolescents. Washington DC: AmericanPsychological Association, 15-52.

9. Barber, B. K., Maughan, S. L. \& Olsen, J. A. (2005). Patterns of parenting across adolescence. New Directions for Child and Adolescent Development, 108, 5-16. https://doi.org/10.1002/cd.124

10. Baumrind, D. (1967). Child care practices anteceding three patterns of preschool behavior. Genetic Psychology Monographs, 75, 43-88.

11. Bean, R. A., Barber, B. K. \& Russell Crane, D. (2006). Parental support, behavioral control, and psychological control among African American Youth. Journal of Family Issues, 27 (10), 1335-1355. https://doi.org/10.1177/0192513X06289649

12. Björqvist, K., Lagerspetz, K. M. J. \& Kaukiainen, A. (1992). Do girls manipulate and boys fight? Developmental trends in regard to direct and indirect aggression. Aggressive Behavior, 18, 117-127.

13. Bolkan, C., Sano, Y., De Costa, J., Acock, A. C. \& Day, R.D. (2010). Early adolescents' perceptions of mothers' and fathers' parenting styles and problem behavior. Marriage and Family Review, 46 (8), 563-579. https://doi.org/10.1080/01494929.2010.543040

\section{4 članci}


14. Booth, C. L., Rose Krasnor, L., McKinnon, J. \& Rubin, K. H. (1994). Predicting social adjustmentin middle childhood: The role of preschool attachment security and maternal style. Social Development, 3, 189-204. https://doi.org/10.1111/j.1467-9507.1994.tb00040.x

15. Bornstein, M. H. (2012). Cultural approaches to parenting. Parenting, Science and Practice, 12 (2-3), 212-221. https://doi.org/10.1080/15295192.2012.683359

16. Bowlby J. (1982). Attachment and loss. New York: Basic Books.

17. Braza, P., Carreras, R., Munoz, J. M., Braza, F., Azurmendi, A., Pascual-Sagastizabal, E., Cardas, J. \& Sanchez-Martin, J. R. (2015). Negative maternal and paternal parenting styles as predictors of children's behavioral problems: Moderating effects of the child's sex. Journal of Child and Family Studies, 24 (4), 847-856.

18. Bronte-Tinkew, J., Moore, K. A. \& Carrano, J. (2006). The father-child relationship, parenting styles, and adolescent risk behaviors in intact families. Journal of Family Issues, 27 (6), 850-881. https://doi.org/10.1177/0192513X05285296

19. Browne, D. T., Odueyungbo A., Thabane L., Byrne C. \& Smart L. A. (2010). Parenting by gender interactions in child psychopathology: Attempting to address inconsistencies with a Canadian national database. Child and Adolescent Psychiatry and Mental Health, 4 (1), 1-20. https://doi.org/10.1186/1753-2000-4-5

20. Buehler, C., Benson, M. J. \& Gerard, J. M. (2006). Interparental hostility and early adolescent problem behavior: The mediating role of specific aspects of parenting. Journal of Research on Adolescence, 16 (2), 265-292.

21. Buschgens, C. J. M., Aken, M. A. G., Swinkels, S. H. N., Ormel, J., Verhulst, F. C. \& Buitelaar J. K. (2010). Externalizing behaviors in preadolescents: familial risk to externalizing behaviors andperceived parenting styles. European Child \& Adolescent Psychiatry, 19 (7), 567-575.

22. Card, N. A., Stucky, B. D., Sawalani, G. M. \& Little, T. D. (2008). Direct and indirect aggression during childhood and adolescence: A meta-analytic review of gender differences, intercorrelations, and relations to maladjustment. Child Development, 79 (5), 1185-1229. https://doi.org/10.1111/j.1467-8624.2008.01184.x

23. Chang, L., Schwartz, D., Dodge, K. A. \& McBride-Chang, C. (2003). Harsh parenting in relation to child emotion regulation and aggression. Journal of Family Psychology, 17 (4), 598-606.

24. Chen, X., Liu, M. \& Li, D. (2000). Parental warmth, control, and indulgence and their relations to adjustment in Chinese children: A longitudinal study. Journal of Family Psychology, 14 (3), 401-419.

25. Chen, X., Rubin, K. \& Li, B. (1997). Maternal acceptance and social and school adjustment in Chinese children: A four-year longitudinal study. Merrill-Palmer Quarterly, 43 (4), 663-681. 
26. Collins, W. A. \& Russell, G. (1991). Mother-child and father-child relationships in middle childhood and adolescence: A developmental analysis. Developmental Review, 11, 99-136.

27. Craig, L. (2006). Does father care mean fathers share? A comparison of how mothers and fathers in intact families spend time with children. Gender \& Society, 20 (2), 259-281. https://doi.org/10.1177/0891243205285212

28. Crick, N. R. \& Grotpeter, J. K. (1995). Relational aggression, gender, and social-psychological adjustment. Child Development, 66 (3), 710-722.

29. Čudina-Obradović, M. \& Obradović, J. (2006). Psihologija braka i obitelji. Zagreb: Golden marketing - Tehnička knjiga.

30. David, C. F. \& Kistner, J. A. (2000). Do positive self-perceptions have a dark side? Examination of the link between perceptial bias and agression. Journal of $A b-$ normal Child Psychology, 28 (4), 327-337.

31. Eliot, M. \& Cornell, D. G. (2009). Bullying in middle school as a function of insecure attachment and aggressive attitudes. School Psychology International, 30 (2), 201-214. https://doi.org/10.1177/0143034309104148

32. Fletcher, A. C., Steinberg, L. \& Williams-Wheeler, M. (2004). Parental influences on adolescent problem behavior: Revisiting Stattin and Kerr. Child Development, 75 (3), 781-796. https://doi.org/10.1111/j.1467-8624.2004.00706.x

33. Garcia, F. \& Gracia, E. (2009). Is always authoritative the optimum parenting style? Evidence from Spanish families. Adolescence, 44 (173), 101-131.

34. Grolnick, W. S., Pomerantz, E. M. (2009). Issues and challenges in studying parental control: Toward a new conceptualization. Child Development Perspectives, 3 (3), 165 - 170. https://doi.org/10.1111/j.1750-8606.2009.00099.x

35. Hart, C. H., Nelson, D. A., Robinson, C. C., Frost Olsen, S. \& McNeilly-Choque, M. K. (1998). Overt and relational aggression in Russian nursery-school-age children: Parenting style and marital linkages. Developmental Psychology, 34 (4), 687-697.

36. Hoeve, M., Dubas J. S., Eichelsheim, V. I., Laan, P. H., Smeenk, W. \& Gerris, J. R. M. (2009). The relationship between parenting and delinquency: A meta-analysis. Journal of Abnormal Child Psychology, 37 (6), 749-775.

37. Hoeve, M., Dubas, J. S., Gerris, J. R. M., van der Laan, P. H. \& Smeenk, W. (2011). Maternal and paternal parenting styles: Unique and combined links to adolescent and early adult delinquency. Journal of Adolescence, 34 (5), 813-827. https:// doi.org/10.1016/j.adolescence.2011.02.004

38. Kawabata, Y. \& Crick, N. R. (2016). Differential associations between maternal and paternal parenting and physical and relational aggression. Asian Journal of Social Psychology, 19 (3), 254-263. https://doi.org/10.1111/ajsp.12139

39. Keresteš, G. (2002). Dječje agresivno i prosocijalno ponašanje u kontekstu rata. Jastrebarsko: Naklada Slap.

\section{6 članci}


40. Keresteš, G., Brković, I., Kuterovac Jagodić, G. \& Greblo, Z. (2012). Razvoj i validacija Upitnika roditeljskog ponašanja. Suvremena psihologija, 15 (1), 23-42.

41. Klarin, M. \& Đerđa, V. (2014). Roditeljsko ponašanje i problemi u ponašanju kod adolescenata. Ljetopis socijalnog rada, 21 (2), 243-262. httsp://10.3935/ljsr.v21i2.17

42. Kline, R. B. (2005). Principles and Practice of Structural Equation Modeling. New York/ London: The Guilford Press.

43. Knezović, D. \& Buško, V. (2007). Percipirano roditeljsko ponašanje i različiti aspekti agresivnoga ponašanja djece osnovnoškolske dobi. Odgojne znanosti, 9 (1), 91-106.

44. Kokkinos C. M. (2014). Bullying and victimization in early adolescence: Associations with attachment style and perceived parenting. Journal of School Violence, 12 (2), 174-192. https://doi.org/10.1080/15388220.2013.766134

45. Kosterman, R., Haggerty, K. P., Spot, R. \& Redmond, C. (2004). Unique influence of mothers and fathers on their children antisocial behavior. Journal of Marriage and Family, 66 (3), 762-778. https://doi.org/10.1111/j.0022-2445.2004.00051.x

46. Kõiv, K. (2012). Attachment styles among bullies, victims and uninvolved adolescents. Psychology Research, 2 (3), 160-165.

47. Kuppens S., Grietens H., Onghena P. \& Michiels D. (2009). Associations between parental control and children's overt and relational aggression. British Journal of Developmental Psychology, 27 (3), 607-623. https://doi.or$\mathrm{g} / 10.1348 / 026151008 \times 345591$

48. Lamb, M. E. (2010). How do fathers influence children's development? Let me count the ways. In: Lamb, M. E. (ed.), The role of the father in child development. New Yersey: John Wiley \& Sons.Inc., 1.

49. Lamb, M. E. \& Lewis, C. (2004). The development and significance of father-child relationship in two-parent families. In: Lamb, M. E. (ed.), The role of the father in child development. New Yersey: John Wiley \& Sons.Inc, 94-153.

50. Lansford, J. E., Laird, R. D., Pettit, G. S., Bates, J. E. \& Dodge, K. A. (2014). Mothers' and fathers' autonomy.relevant parenting: Longitudinal links with adolescents' externalizing and internalizing behavior. Journal of Youth and Adolescence, 43 (11), 1877-1889.

51. Laukkanen, J., Ojansuu, U., Tolvanen, A., Alatupa, S. \& Aunola, K. (2014). Child's difficult temperament and mothers' parenting styles. Journal of Child and Family Studies, 23 (2), 312-323.

52. Little T. D., Jones S. M., Henrich C. C. \& Hawley P. H. (2003). Disentangling the "whys « from the "whats" of aggressive behavior. International Journal of Behavioral Development, 27 (2),122-133. https://doi.org/10.1080/01650250244000128

53. Maccoby, E. E. (2007). Historical overview of socialization research and theory. In: J. E. Grusec, J. E. \& Hastings, P. D. (eds.), Handbook of socialization: Theory and research. New York: Guilford Press, 13-41. 
54. Macuka, I. (2010). Osobne i kontekstualne odrednice roditeljskog ponašanja. Suvremena psihologija, 13 (1), 63-81.

55. Macuka, I. \& Smojver-Ažić, S. (2012). Osobni i obiteljski čimbenici prilagodbe mlađih adolescenata. Hrvatska revija za rehabilitacijska istraživanja, 18 (1), 27-43.

56. Macuka, I., Smojver-Ažić, S. \& Burić, I. (2011). Posredujuća uloga emocionalne regulacije u odnosu roditeljskog ponašanja i prilagodbe mlađih adolescenata. Društvena istraživanja, 116 (2), 383-403.

57. Mak, A. S. (1994). Parental neglect and overprotection as risk factors in delinquency. Australian Journal of Psychology, 46 (2), 107-111.

58. Marsee M. A. \& Frick P. J. (2007). Exploring the cognitive and emotional correlates to proactive and reactive aggression in a sample of detained girls. Journal of Abnormal Child Psychology, 35 (6), 969-981.

59. McDermott Panetta, S., Somers, C. L., Ceresnie, A. R., Hillman, S. B. \& Partridge, R. T. (2014). Maternal and paternal parenting style patterns and adolescent emotional and behavioral outcomes. Marriage and Family Review, 50 (4), 342-359. https://doi.org/10.1080/01494929.2013.879557

60. McKee, L., Roland, E., Coffelt, N., Olson, A. L., Forehand, R., Massari, C., Jones, D., Gaffney, C. A.\&Zens, M. S. (2007). Harsh discipline and child problem behaviors: The roles of positive parenting and gender. Journal of Family Violence, 22 (4), 187-196.

61. McMunn, A., Martin, P., Kelly, Y.\& Sacker, A. (2017). Fathers' involvement: Correlates and consequences for child socioemotional behavior in the United Kingdom. Journal of Family Issues, 38 (8), 1109-1131. https://doi.org/10.1177/0192513X15622415

62. Nelson, D. A. \& Crick, N. R. (2002). Parental psychological control: implications for childhood physical and relational aggression. In: Barber, B. K. (ed.), Intrusive parenting. Washington DC: American Psychological Association, 161-189.

63. Nelson, D. A., Hart, C. H., Yang, C., Olsen, J. A. \& Jin, S. (2006). Aversive parenting in China: Associations with child physical and relational aggression. Child Development, 77 (3), 554-572. https://doi.org/10.1111/j.1467-8624.2006.00890.x

64. Newland, L. A. \& Coyl, D. C. (2010). Fathers' role as an attachment figures: an interview with Sir Richard Bowlby. Early Child Development and Care, 180 (1-2), 25-32. https://doi.org/10.1080/03004430903414679

65. Nichols, T. R., Graber, J. A. \& Brooks-Gunn, Botvin, G. J. (2006). Sex differences in overt agression and delinquency among urban minority middle school students. Applied Developmental Psychology, 27 (1), 78-91. https://doi.org/10.1016/j. appdev.2005.12.006

66. Olivari, M. G., Hertfelt Wahn, E., Maridaki-Kassotaki, K., Antonopoulu, K. \& Confalonieri, E. (2015). Adolescent perceptions of parentin styles in Sweden, Italy and Greece: An exploratory study. Europe's Journal of Psychology, 11 (2), 244-258. hhtps:// 10.5964/ejop.v11i2.887

\section{8 članci}


67. Paquette, D. (2004). Theorizing the father-child relationship: Mechanisms and developmental outcomes. Human Development, 47, 193-219.

68. Patterson, C. J., Cohn, D. A. \& Kao, B. T. (1989). Maternal warmth as a protective factor against risks associated with peer rejection among children. Development \& Psychopathology, 1 (1), 21-38. https://doi.org/10.1017/S0954579400000225

69. Pettit, G. S., Laird, R. D., Dodge, K. A., Bates, J. E. \& Criss, M. M. (2001). Antecedents and behavior-problem outcomes of parental monitoring and psychological control in early adolescence. Child Development, 72 (2), 583-598. https://doi. org/10.1111/1467-8624.00298

70. Putnam, S. P., Sanson, A. V. \& Rothbart, M. K. (2002). Child temperament and parenting. In: Bornstein, M. H. (ed.), Handbook of parenting. Volume 1. Children and parenting. Mahwah: Lawrence Earlbaum Associates, 255-278.

71. Rogers, K. N., Buchanan, C. M. \& Winchell, M. E. (2003). Psychological control during early adolescence: Links to adjustment in differing parent/adolescent dyads. Journal of Early Adolescence, 23(4), 349-383.

72. Rothbart, M. K. \& Maccoby, E. E. (1966). Parents' differential reactions to sons and daughters. Journal of Personality and Social Psychology, 4 (3), 237-243.

73. Rothbaum, F. \& Pott, M. (1991). Parental caregiving and child externalizing behavior in nonclinical samples: A meta-analysis. Seattle: WA.

74. Salmivalli, C. \& Kaukiainen, A. (2004). »Female aggression« revisited: Variable- and person-centered approaches to studying gender differences in different types of aggression. Aggressive behavior, 30 (2), 158-163. https://doi.org/10.1002/ab.20012

75. Sandstrom, M. J. (2007). A link between mothers' disciplinary strategies and children's relational aggression. British Journal of Developmental Psychology, 25 (3), 399-407. https://doi.org/10.1348/026151006X158753

76. Smith, R. L., Rose, A. J. \& Schwartz-Mette, R. A. (2010). Relational and overt aggression in childhood and adolescence: Clarifying mean-level gender differences and associations with peer acceptance. Social Development, 19 (2), 243-269. https://doi.org/10.1111/j.1467-9507.2009.00541.x

77. Smits, D. J. M., De Boeck, P. \& Vansteelandt, K. (2004). The inhibition of verbally agressive behaviour. European Journal of Personality, 18 (7), 537-555. https://doi. org/10.1002/per.529

78. Soenens, B., Luyckx, K., Vansteenkiste, M., Duriez, B. \& Goossens L. (2008). Clarifying the link between parental psychological control and adolescents' depressive symptoms. Merrill Palmer Quarterly, 54 (4), 411-444.

79. Starrels, M. E. (1994). Gender differences in parent-child relations. Journal of Family Issues, 15 (1), 148-165.

80. Stattin, H. \& Kerr M. (2000). Parental monitoring: A reinterpretation. Child Development, 71, 1072-1085. 
81. Šarić, M. (2017). Uloga osjetljivosti na potkrepljenje i percipiranog roditeljskog ponašanja u pojavi proaktivne i reaktivne agresije kod adolescenata. Doktorska disertacija. Zagreb: Filozofski fakultet.

82. Tabachnick, B. G. \& Fidell, L. S. (2001). Using Multivariate Statistics. Needham Heights, MA: Allyn \& Bacon, A Pearson Education Company.

83. Tavassolie, T., Dudding, S., Madigan, A. L., \& Thorvardarson, E. (2016). Differences in perceived parenting style between mothers and fathers: Implications for child outcomes and marital conflict. Journal of Child and Family Studies, 25 (6), 2055-2068.

84. Tung, I., Li, J. J. \& Lee, S.S. (2012). Child sex moderates the asociations between negative parenting and childhood conduct problems. Aggressive Behavior, 38 (3), 239-251. https://doi.org/10.1002/ab.21423

85. Wijsbroek, S. A. M., Hale, W. W., Raaijmakers, Q. A. W. \& Meeus, W. H. J. (2011). The direction of effects between perceived parental behavioral control and psychological control and adolescents' self-reported GAD and SAD symptoms. European Child \& Adolescent Psychiatry, 20 (7), 361-371.

86. 90. Winsler, A., Madigan, A. L. \& Aqulino, S. A. (2005). Correspondence between maternal and paternal parenting style in early childhood. Early Childhood Research Quarterly, 20 (1), 1-12. https://doi.org/10.1016/j.ecresq.2005.01.007

87. Zimmer-Gembeck, M. J., Geiger, T. C. \& Crick, N. R. (2005.) Relational and physical aggression, prosocial behavior, and peer relations: Gender moderation and bidirectional associations. Journal of Early Adolescence, 25, 421-452. https://doi. org/10.1177/0272431605279841 
Marija Šarić Drnas

Tea Pavin Ivanec

Renata Miljević- Riđički

University of Zagreb

Faculty of Teacher Education

\title{
THE RELATIONSHIP BETWEEN PARENTAL BEHAVIOUR AND OVERT AND RELATIONAL AGGRESSION IN ADOLESCENTS
}

\begin{abstract}
The aim of this study was to investigate whether overt and relational aggression of adolescent boys and girls can be predicted based on the behaviour of their mothers and fathers, and whether the role of parental behaviour in explaining aggressive behaviour depends on the gender of the child and parent. The study included 605 participants (273 girls and 332 boys), third grade secondary school students. Data on overt and relational aggressive behaviour of adolescents was collected by administering the Peer Conflict Scale questionnaire (Marsee i Frick, 2007), while data on the perception of parental behaviour was collected administering the Parental Behaviour Questionnaire (Keresteš et al., 2012). The results show that boys generally exhibit higher degrees of overt aggression and that they perceive fathers as more supportive and less permissive compared to girls. As regards overt aggression of boys, regression analysis has shown that a significant predictor is higher mother's restrictive control, while predictors of overt aggression of girls included higher mother's restrictive control and permissiveness and less father's parental support. The important predictors of relational aggression in boys and girls are higher mother's and father's restrictive control, lower father's support and higher mother's permissiveness. The results of the study contribute to understanding of the complex relationship between parental behaviour and aggressive behaviour of adolescents, they can be useful to various specialists working with adolescents and their parents, and can be applied in designing and implementing programmes to raise awareness of the importance of parental behaviour and how parent and child behaviour are interrelated, both generally and in the context of gender differences.
\end{abstract}

Key words: overt aggression, relational aggression, adolescence, parental behaviour.

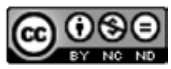

Međunarodna licenca / International License:

Creative Commons Attribution-NonCommercial-NoDerivatives 4.0. 
